\title{
SEARCH FOR SCUTELLONEMA BRADYS RESISTANCE IN YAMS (DIOSCOREA SPP.)
}

\author{
C. K. Kwoseh ${ }^{1}$, R. A. Plowright ${ }^{2}$, J. Bridge ${ }^{2}$ and R. Asiedu ${ }^{3}$ \\ ${ }^{1}$ Department of Crop and Soil Sciences, \\ Kwame Nkrumah University of Science and Technology, Kumasi, Ghana \\ ${ }^{2}$ CABI Bioscience UK Centre, Bakeham Lane, Egham, Surrey TW20 9TY, UK \\ ${ }^{3}$ International Institute of Tropical Agriculture (Nigeria), c/o LW Lambourn and Co., Carolyn House, \\ 26 Dingwall Road, Croydon CR9 3EE, UK
}

\begin{abstract}
A study to examine variability in susceptibility of yams to Scutellonema bradys and to identify possible sources of resistance in Ghanaian yam germplasm (Dioscorea spp.) for use in yam improvement programmes, particularly, in West Africa was undertaken. Pot and field screening methodologies were used. In general, S. bradys and dry rot of tuber symptoms as well as tuber cracking increased during the storage period. The study showed a positive correlation between visual nematode damage and population densities in yam tubers. There was also a linear relationship between dry rot disease and tuber cracking at harvest and during storage. This confirms that $S$. bradys causes dry rot of tubers resulting in external cracking of yam tubers. Positive linear relationship was also observed between yam tuber weight loss and dry rot disease indicating that dry rot disease may have contributed to the tuber weight loss. Therefore, tuber dry rot symptoms caused by S. bradys of yams could be used to discard susceptible yams at harvest and after a period of storage. However, there was no linear relationship between nematode population densities in yam tubers and roots, therefore, a root protocol cannot be used for assessing resistance in yams as it could lead to misclassification. The yam germplasm screened, reaffirmed resistance to S. bradys in Dioscorea dumetorum var. Nkanfo and D. cayenensis var. Afun.
\end{abstract}

Keywords: Scutellonema bradys, Nematode, Dioscorea, Yam, Resistance

\section{INTRODUCTION}

The yam nematode, Scutellonema bradys is a major nematode pest of yams, particularly, in West Africa causing severe damage to yam tubers (Adesiyan et al., 1990; Jatala and Bridge, 1990; Emehute et al., 1998). It is the most important and prevalent nematode on yam in
Ghana (Plowright and Kwoseh, 1998), largely determining yam tuber quality and storability. They can cause a reduction of $20-30 \%$ in tuber weight at harvest (Smit, 1967). According to Coursey (1967), nematode infection contributes to long term storage losses and has been estimated as $50 \%$. In severe cases, loss may be total. 
S. bradys also acts as wounding agents and creates infection courts in tuber for fungi and bacteria to gain entry easily and cause wet rot (Bridge, 1982).

Yams, when grown as a subsistence crop, are generally not treated with pesticides and chemical treatments are not widely used for nematode control. Farmers have therefore relied on natural variation for their selection of suitable varieties of yam to cope with the damage caused by plant parasitic nematodes. Nematode resistant yam cultivars can be one of the most useful, economical and effective means of managing nematodes for resource-poor farmers. New and more productive varieties with resistance to nematodes are therefore, needed to increase and sustain productivity of yam cultivation.

Asiedu et al. (1998) showed that there is hope for the existence and management of genetic resistance in Dioscorea spp. According to Degras (1993) and Akoroda and Hahn (1995), substantial research investment has been made in the control of diseases and pests of yams and these efforts are continuing. However, the breeding for resistance against yam nematodes has been one of the most neglected research areas. This may be because of the genetically complex nature of the crop (Akoroda and Hahn, 1995) and few trained nematologists pursuing this goal. To breed such genotypes, sources of resistance in yams need to be identified. Also, reliable and reproducible screening methods are essential since escapes or misclassifications waste breeding effort and these have been developed and refined (Kwoseh et al. 2002). The objectives of this research were therefore to examine the variations in susceptibility of Dioscorea spp. to Scutellonema bradys, and identify sources of resistance for use in yam improvement programmes. The term 'resistance' in the context of this study refers to the degree of difficulty of multiplication of the nematode in either yam roots or tuber tissues (Cook and Evans, 1987).

\section{MATERIALS AND METHODS}

Juvenile and adult stages of Scutelonema bradys obtained from $S$. bradys-infected yam peelings was used for inoculation. The $S$. bradys populations were collected from various farmers' fields in the major yam growing zones in Ghana and the Kumasi Central market.

The yams used for the studies were obtained during a farmer-pest appraisal in the major yam agroecological zones in Ghana. Local and traditional yam varieties or landraces were collected from almost all the towns and villages visited in the districts. Selected yam varieties were screened for $S$. bradys resistance in pot and field experiments.

Yam plants were raised using the yam minisetts technique (Otoo et al., 1987). In this technique, the head region of the yam tuber was cut off and then the other portions sectioned horizontally into discs. Each disc was cut into parts with peel of the tuber. Setts weighing about $40 \mathrm{~g}$ were used for pot trials and $100 \mathrm{~g}$ for field trials. The cut surfaces of the setts were treated with Benlate-wood ash mix. The treated setts were then pre-sprouted in a quantity of sterilised moist coco-peat (shredded coconut husk) in plastic boxes in the screenhouse. The coco-peat was moistened with Benlate, a systemic fungicide $(25 \mathrm{~g} / 11$ litre water). The treated setts were spread on top of the coco-peat in a plastic box and then covered with another layer of moist coco-peat. This method was used to obtain more uniform plant establishment, tuber size and tuber maturity. Uniform plants of about 4 weeks old were used for the experiments.

\section{Assessment of yam varieties for nematode resistance}

Three sets of experiments were conducted to evaluate the reaction of test yam varieties of $D$. rotundata, D. alata, D. cayenesis, D. bulbifera, $D$. esculenta and D. dumetorum to $S$. bradys

\author{
Experiment 1: \\ Field evaluation of 40 Ghanaian yam varieties \\ for S. bradys resistance
}

34 Journal of Science and Technology, Vol. 27, No. 3, December 2007 
A total of 40 Ghanaian yam varieties $(26$ D. rotundata, two D. cayenensis, 11 D. alata and one $D$. dumetorum ) were screened for their reaction to $S$. bradys in a field experiment at the Crops Research Institute (CRI), Kumasi, Ghana (Table 1). Uniform plants from $100 \mathrm{~g}$ minisetts obtained as explained above were transplanted in mounds four weeks after sprouting at $1 \mathrm{~m}$ x $1 \mathrm{~m}$ planting spacing.

Two weeks after planting, each plant in the mound was infested with about 6,000 juvenile and adult stages of $S$. bradys (50 g $S$. bradysinfected yam peelings). A trench of about $5 \mathrm{~cm}$ from the stem of each plant was made around the plants in the mound and at a depth that exposed some of the roots. The chopped infected tuber peelings were then spread around the roots and covered again with the soil. A randomised complete block design (RCBD) with four replicates was used. The entries were harvested 36 weeks after transplanting and stored in baskets kept in an open-air yam barn. Visual nematode damage symptoms score (Kwoseh et al., 2002) and weight of tubers were recorded at harvest and at four and 11 weeks after harvest.

Each of the tubers in the screen was washed and peeled from the proximal to the distal end at two places and opposite to one another at four and 11 weeks after harvest for nematode extraction and counting. The yam tuber peelings were then chopped into 3 to $4 \mathrm{~mm}$ wide and about $1 \mathrm{~cm}$ long pieces for nematode extraction. Nematodes were extracted by the modified Baermann tray method (Whitehead and Hemming, 1965).

\section{Experiment 2:}

Confirmation test of 10 selected Ghanaian yam varieties of $D$. rotundata, $D$. cayenensis, $D$. alata and D. dumetorum for $S$. bradys resistance

Based on the results of Experiment 1 above, 10 different varieties and species of $D$. rotundata, $D$. cayenensis, D. alata and D. dumetorum namely Lili (D. rotundata), Chenchito (D. rotundata), Agyaasi (D. alata), Afun (D. cayenensis),
Yeremma (D. alata), Adi-amaaba (D. alata), Sante $(D$. rotundata), Matches (D. alata), Saabiri (D. alata) and Nkanfo (D. dumetorum) were used for a confirmation test in a field experiment. The study was done at the Crops Research Institute, Kumasi, Ghana. Plants from $100 \mathrm{~g}$ minisetts were pre-sprouted and planted in mounds. A randomised complete block design with five replicates was used.

The plants were infested with about 1,700 juvenile and adult stages of $S$. bradys $(50 \mathrm{~g} S$. bradysinfected yam peelings) two weeks after transplanting as in Experiment 1. The experiments were conducted at different seasons or times therefore peelings from the $S$. bradys-infested yam tubers used as sources of inoculum were different from Experiments 1 and 3. The entries were harvested 28 weeks after transplanting and then stored. Visual nematode injury score and tuber weight were recorded at harvest and eight weeks after storage. Each tuber was peeled and chopped eight weeks after storage and S. bradys was extracted and counted as described in Experiment 1.

\section{Experiment 3:}

Pot screening of seven selected Ghanaian yam varieties of $D$. rotundata, $D$. cayenensis, $D$. alata, D. dumetorum, D. bulbifera and D. esculenta for $S$. bradys resistance

Seven different yam varieties (D. rotundata var. Kyire-Kumasi, D. rotundata var. Chenchito $D$. rotundata var. Lili, D. cayenensis var. Afun, D. dumetorum var. Nkanfo and unknown variety of $D$. bulbifera plus an unknown variety of $D$. esculenta were evaluated in a pot experiment at the Department of Crop and Soil Sciences, Kwame Nkrumah University of Science and Technology, Kumasi, Ghana. Minisetts of $40 \mathrm{~g}$ of the yams were treated and pre-sprouted in sterilised cocopeat as described above. About four-week old plants of these yams were each potted into twolitre size pots containing about 1.5 litres of heat sterilised 2:1 soil-cocopeat mix. A simple line screening design with five replicates was used. 
The potted plants were allowed three weeks in the screenhouse to establish and then were each inoculated with about 800 active juvenile and adult stages of $S$. bradys (50 g chopped $S$. bra$d y s$-infected tuber peelings) in a similar way as described in Experiment 1. The inoculated plants were harvested nine weeks after inoculation. Roots and tubers of all test plants were washed and fresh weights taken separately and symptoms of nematode injury were scored (Kwoseh et al., 2002). Nematodes were extracted from washed roots or tuber peelings and the number of $S$. bradys counted. Each tuber was completely peeled. The roots or tuber peelings for each entry were chopped separately with a pair of scissors and then $5 \mathrm{~g}$ tissue of each was placed on to a two-ply facial tissue supported on a sieve placed in a plate. The set-up was left for $48 \mathrm{~h}$ under ambient conditions in the laboratory to collect the nematodes in a water suspension.

Data were transformed using square root for nematode counts and arcsin for percentages. Analyses of data were made using SAS Software Release 6.12 (1996).

\section{RESULTS AND DISCUSSION}

Experiment 1: Field evaluation of Ghanaian yam varieties for $\boldsymbol{S}$. bradys resistance

Analysis of variance revealed highly significant differences $(\mathrm{P}>0.001)$ between the yam varieties screened for $S$. bradys reaction. Mean $S$. bradys counts at four weeks ranged from 0 to $1073 / 5 \mathrm{~g}$ and from 0 to $1050 / 5 \mathrm{~g}$ at 11 weeks after storage (Table 1).

In general, the number of S. bradys and dry rot of tuber as well as tuber cracking increased during the storage period (Table 1). Dry rot and tuber cracking at harvest and after 11 weeks of tuber storage showed significant differences ( $P$ $>0.01)$ between varieties. The coefficients of variation $(\mathrm{CV})$ for the variables were high (Table 1). This may be because of the high variation in susceptibility between varieties.

It was observed that severely infected yam tu- bers with severe rot and cracking had large nematode populations. However, some infected tubers with symptoms recorded low nematodes counts (Table 1, e.g. TDr Labarko) probably because these tubers were either dried out or completely destroyed by dry rot disease with very little or no living tissue remaining.

Strong correlation $(r=0.9, r=0.5$ and $r=0.7)$ occurred between internal dry rot and tuber cracking at harvest and at four and 11 weeks after storage respectively. Dry rot of tubers also correlated positively $(\mathrm{r}=0.6)$ with $S$. bradys populations in the yam tubers. This relationship confirms that (Bridge et al., 2005) S. bradys causes internal dry rot of tubers resulting in external cracking of yam tubers. Following these results, dry rot symptoms could be effectively used to select for resistance to $S$. bradys in yam tubers either at harvest or after about four weeks of storage.

Based on $S$. bradys populations, all the Ghanaian yam varieties of $D$. rotundata and $D$. alata screened were susceptible. This agrees with Adesiyan (1977) and Bridge (1982) who examined yam cultivars from West Africa. D. dumetorum var. Nkanfo and D. cayenesis var. Afun were found to be resistant. D. dumetorum var. Nkanfo did not support reproduction and was not damaged by the nematode. According to Bridge et al. (2005), D. dumetorum is generally considered to be less susceptible to nematodes. In this study, these yams are considered resistant because they had zero or relatively low dry rot indices and supported very small nematode populations (Table 1).

\section{Experiment 2:}

Confirmation test of selected Ghanaian yam varieties of $D$. rotundata, $D$. cayenensis, $D$. alata and $D$. dumetorum for $S$. bradys resistance

The yam varieties generally produced large numbers of $S$. bradys in the tubers except on D. dumetorum var. Nkanfo and D. cayenensis var. Afun that recorded significantly smaller numbers

36 Journal of Science and Technology, Vol. 27, No. 3, December 2007 
Table 1: Reaction of Ghanaian yam varieties of D. rotundata (TDr), D. alata (TDa), D. cayenensis (TDc) and $D$. dumetorum (TDd) to $S$. bradys infection and populations in tubers after four and eleven weeks storage

\begin{tabular}{|c|c|c|c|c|c|c|c|c|c|c|}
\hline \multirow[b]{2}{*}{ Yam variety } & \multicolumn{3}{|c|}{${ }^{\mathrm{a}}$ Mean dry rot index } & \multicolumn{3}{|c|}{ Mean tuber cracking } & \multicolumn{4}{|c|}{$\begin{array}{l}\text { *Mean no. } S \text {. } \text { bradys } / 5 \text { g tuber peelings } \\
\text { Transformed }\end{array}$} \\
\hline & Harvest & $4 w k$ & $11 w k$ & Harvest & $4 \mathrm{wk}$ & $11 \mathrm{wk}$ & $4 \mathrm{wk}$ & $11 \mathrm{wk}$ & & ${ }^{b}$ Reaction \\
\hline TDa Yeremma & 1.5 & 1.5 & 2.3 & 1.5 & 1.3 & 2.0 & $31.9(8.8)$ & $29.5(15.4)$ & a & $\mathrm{S}$ \\
\hline TDa Saabiri & 0.5 & 1.3 & 1.8 & 1.0 & 1.3 & 1.8 & $18.5(9.3)$ & $28.1(16.4)$ & $a b$ & $\mathrm{~S}$ \\
\hline TDr Afi & 0.7 & 2.0 & 2.3 & 1.3 & 1.3 & 2.0 & $25.1(4.9)$ & $27.9(11.2)$ & $a b$ & $\mathrm{~S}$ \\
\hline TDr Sante & 0.5 & 1.3 & 2.0 & 1.3 & 1.0 & 1.5 & $27.2(13.3)$ & $27.8(11.5)$ & $\mathrm{abc}$ & $\mathrm{S}$ \\
\hline TDa Matches & 1.5 & 2.0 & 2.3 & 1.5 & 1.0 & 1.8 & $21.4(8.9)$ & $27.2(13.2)$ & $a-d$ & $\mathrm{~S}$ \\
\hline TDa Mmrefi & 0.5 & 0.8 & 1.3 & 1.0 & 1.0 & 1.0 & $15.1(16.4)$ & $25.8(14.3)$ & $a-d$ & $\mathrm{~S}$ \\
\hline TDr Nigeria & 1.0 & 1.5 & 2.0 & 1.0 & 1.3 & 1.8 & $29.9(12.2)$ & $25.7(14.0)$ & $a-d$ & $\mathrm{~S}$ \\
\hline TDa Afasie Kwandwo & 0.5 & 1.0 & 2.0 & 1.0 & 1.3 & 1.8 & $19.1(12.2)$ & $25.7(10.8)$ & a-d & $\mathrm{S}$ \\
\hline TDa Datordi & 1.8 & 2.0 & 2.5 & 1.8 & 2.0 & 1.8 & $29.5(9.3)$ & $24.9(11.1)$ & a-e & $\mathrm{S}$ \\
\hline TDr Accra & 2.0 & 2.0 & 2.3 & 2.0 & 1.5 & 2.0 & $29.0(5.7)$ & $21.5(7.8)$ & a-e & $\mathrm{S}$ \\
\hline TDr Tempe & 1.3 & 1.8 & 2.0 & 1.5 & 1.3 & 1.5 & $21.2(5.2)$ & $20.5(7.9)$ & a-e & $\mathrm{S}$ \\
\hline TDa Nsoadansi & 1.0 & 1.5 & 2.0 & 1.0 & 1.0 & 2.0 & $21.2(5.3)$ & $20.4(2.5)$ & a-e & $\mathrm{S}$ \\
\hline TDr Puna & 2.3 & 2.3 & 2.5 & 2.3 & 2.3 & 2.0 & $18.2(7.5)$ & $19.1(12.9)$ & $a-f$ & $\mathrm{~S}$ \\
\hline TDa Kyemogo & 0.8 & 1.0 & 1.3 & 1.3 & 1.3 & 1.3 & $16.8(7.9)$ & $18.8(6.0)$ & $a-f$ & $\mathrm{~S}$ \\
\hline TDc Abrewa nwo & 1.5 & 2.3 & 2.5 & 1.3 & 1.3 & 1.8 & $22.9(10.0)$ & $18.7(8.0)$ & $a-f$ & $\mathrm{~S}$ \\
\hline TDr Kpirindwo & 2.3 & 1.7 & 2.3 & 2.3 & 1.3 & 2.0 & $21.8(3.4)$ & $17.1(6.6)$ & $a-f$ & $\mathrm{~S}$ \\
\hline TDr Sanyata & 2.3 & 2.3 & 2.8 & 2.0 & 1.8 & 2.0 & $22.3(7.6)$ & $16.9(7.8)$ & $a-f$ & $\mathrm{~S}$ \\
\hline TDa Akaba & 1.8 & 2.5 & 2.5 & 1.5 & 1.5 & 1.8 & $27.7(4.9)$ & $16.8(7.1)$ & $a-f$ & $\mathrm{~S}$ \\
\hline TDr.Zong & 1.5 & 2.0 & 2.8 & 1.5 & 1.8 & 2.3 & $25.4(12.7)$ & $15.9(8.5)$ & $a-g$ & $\mathrm{~S}$ \\
\hline TDr Ziglanbgo & 0.8 & 1.8 & 1.5 & 1.3 & 1.5 & 1.5 & $21.5(10.8)$ & $15.2(7.6)$ & $\mathrm{a}-\mathrm{h}$ & $\mathrm{S}$ \\
\hline TDr Serwaah & 2.3 & 2.3 & 3.0 & 2.3 & 2.0 & 2.3 & $22.8(2.5)$ & $15.2(1.7)$ & $\mathrm{a}-\mathrm{h}$ & $\mathrm{S}$ \\
\hline TDa Kwaa-Asamoah & 1.3 & 2.0 & 2.0 & 1.3 & 1.3 & 1.5 & $35.0(11.4)$ & $14.6(4.6)$ & $\mathrm{b}-\mathrm{h}$ & $\mathrm{S}$ \\
\hline TDr Denteh & 1.3 & 1.5 & 2.0 & 1.5 & 1.3 & 1.5 & $15.3(3.5)$ & $13.7(3.7)$ & b-h & $\mathrm{S}$ \\
\hline TDr Dakpam & 1.3 & 1.0 & 1.5 & 1.5 & 1.3 & 1.5 & $11.6(8.9)$ & $13.1(8.8)$ & $\mathrm{c}-\mathrm{h}$ & $\mathrm{S}$ \\
\hline TDr Limor & 2.3 & 2.5 & 2.8 & 2.3 & 2.0 & 2.3 & $21.5(4.6)$ & $12.9(2.5)$ & $\mathrm{c}-\mathrm{h}$ & $\mathrm{S}$ \\
\hline TDr Sono bayere & 1.8 & 2.0 & 2.5 & 1.8 & 1.5 & 2.0 & $25.3(11.2)$ & $12.9(1.8)$ & $\mathrm{c}-\mathrm{h}$ & $\mathrm{S}$ \\
\hline TDr Moninyoli & 2.0 & 1.8 & 2.5 & 2.0 & 2.0 & 2.3 & $23.6(10.9)$ & $12.0(3.6)$ & $\mathrm{d}-\mathrm{h}$ & $\mathrm{S}$ \\
\hline TDr Muchumudu & 2.0 & 1.8 & 2.8 & 2.0 & 2.0 & 2.5 & $20.8(10.6)$ & $10.8(3.5)$ & $\mathrm{e}-\mathrm{h}$ & $\mathrm{S}$ \\
\hline TDr Dakorba & 2.0 & 2.0 & 2.5 & 2.0 & 1.8 & 2.5 & $17.7(2.2)$ & $10.0(7.0)$ & e-h & $\mathrm{S}$ \\
\hline TDr Kyire-Kumasi & 1.3 & 1.7 & 2.0 & 1.7 & 1.0 & 1.7 & $18.8(4.9)$ & $9.5(2.7)$ & e-h & $\mathrm{S}$ \\
\hline TDr Agyaasi & 1.3 & 1.5 & 2.3 & 1.0 & 1.3 & 1.8 & $15.4(4.1)$ & $9.2(1.0)$ & e-h & $\mathrm{S}$ \\
\hline TDr Kpiringa & 2.0 & 2.3 & 3.0 & 2.0 & 1.8 & 2.0 & $21.0(6.1)$ & $8.9(4.3)$ & $\mathrm{e}-\mathrm{h}$ & $\mathrm{S}$ \\
\hline TDr Chenchito & 2.5 & 2.5 & 3.0 & 2.0 & 2.0 & 2.5 & $27.7(4.9)$ & $8.9(4.0)$ & $\mathrm{e}-\mathrm{h}$ & $\mathrm{S}$ \\
\hline TDr Lili & 1.0 & 1.5 & 2.3 & 1.3 & 1.3 & 1.8 & $18.9(13.4)$ & $8.2(8.9)$ & e-h & $\mathrm{S}$ \\
\hline TDr Labarko & 2.0 & 2.0 & 2.7 & 2.3 & 2.7 & 2.7 & $7.7(4.3)$ & $7.2(4.9)$ & $e-h$ & $\mathrm{~S}$ \\
\hline TDr Fugla & 1.5 & 1.5 & 2.8 & 1.8 & 1.5 & 2.0 & $12.8(9.2)$ & $5.6(3.0)$ & fgh & $\mathrm{S}$ \\
\hline TDr Tela & 0.8 & 1.3 & 1.3 & 1.3 & 1.0 & 1.5 & $16.9(11.3)$ & $5.0(2.0)$ & fgh & $\mathrm{S}$ \\
\hline TDa Adi-amaaba & 0.5 & 1.0 & 0.8 & 0.8 & 1.0 & 1.0 & $8.3(4.6)$ & $4.7(5.7)$ & fgh & $\mathrm{S}$ \\
\hline TDc Afun & 0.3 & 0.3 & 0.3 & 0.8 & 1.0 & 1.0 & $1.6(1.2)$ & $1.8(1.5)$ & gh & $\mathrm{R}$ \\
\hline TDd Nkanfo & 00 & 00 & 00 & 0.5 & 0.5 & 1.0 & $0.7(0.0)$ & $0.7(0.0)$ & $\mathrm{h}$ & $\mathrm{R}$ \\
\hline $\mathrm{CV}(\%)$ & 58.4 & 35.9 & 31.3 & 39.1 & 34.9 & 25.3 & 42.9 & 50.3 & & \\
\hline
\end{tabular}

*Square root (Mean +0.5$)$ and SAS adjusted for missing data. ${ }^{a}$ Average of 4 replicates. Standard deviation in parentheses. Varieties followed by the same letter do not differ significantly according to Duncan's Multiple Range Test. ${ }^{b} S=$ susceptible, $R=$ resistant 
(Figure 1). D. alata var. Yeremma and D. rotundata var. Lili recorded the largest nematode counts (Figure 1). Dry rot and tuber cracking also differed significantly $(\mathrm{P}>0.01)$ between yam varieties in storage with $D$. rotundata var. Lili and D. alata var. Yeremma registering comparatively high dry rot disease scores (Table 2). This indicates that these visual disease symptoms are useful parameters for rating host resistance or susceptibility in yams.

In most cases, high dry rot symptoms were associated with high nematode numbers. There was strong correlation $(\mathrm{r}=0.7)$ between internal dry rot in tubers and $S$. bradys populations in tubers. Tuber cracking also strongly correlated $(\mathrm{r}=0.8)$ with internal dry rot symptoms.

Tuber weight loss of 16.0 to $74.5 \%$ was recorded over the eight-week storage period with $D$. rotundata var. Sante recording the largest weight loss while $D$. dumetorum var Nkanfo was the least affected (Table 2). Tuber weight reduction among the yam varieties was substantial and highly significant differences $(\mathrm{P}<0.01)$ were observed between them.

There was correlation $(\mathrm{r}=0.4)$ between tuber weight loss and dry rot disease. These results indicate that dry rot disease may have contributed to the tuber weight loss. According to Smit (1967), S. bradys caused a reduction of $20-30 \%$ in tuber weight. This study followed a similar trend as reported in the previous field trial (Experiment 1) and confirmed low multiplication of $S$. bradys in D. dumetorum var Nkanfo and D. cayenensis var. Afun (Figure 1).

S. bradys multiplied in the roots of all the yams in the screen with $D$. dumetorum recording the smallest numbers while, D. esculenta had the largest (Figure 2) although numbers in roots did not differ. It is interesting to have susceptible roots because this is likely to reduce pressure on the tuber.

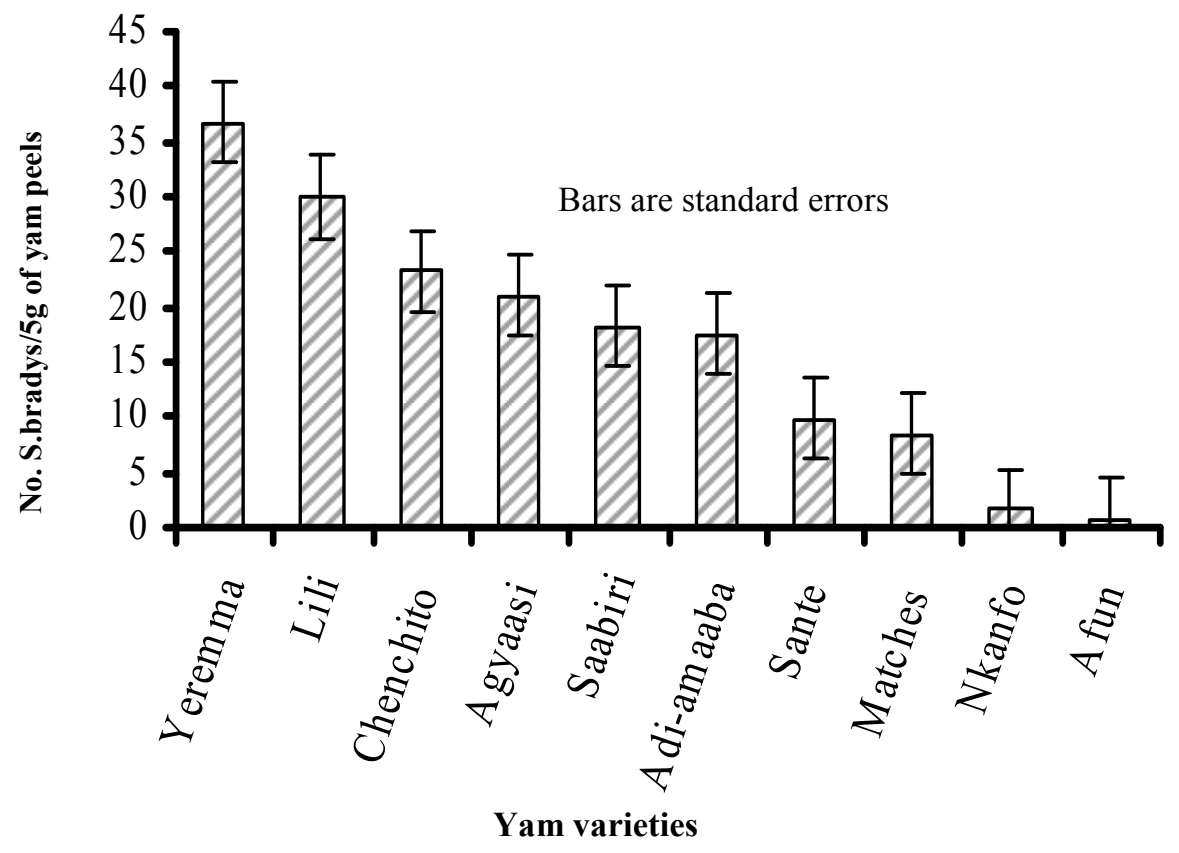

Fig. 1. Square root transformed populations of $S$. bradys in yams after eight weeks storage 
S. bradys numbers were generally larger in roots than in tubers with the resistors recording the smallest numbers (Figure 2). There were highly significant differences $(\mathrm{P}>0.01)$ between the yam varieties regarding $S$. bradys populations in the tubers.

Experiment 3: Pot screening of selected Ghanaian yam varieties for $\boldsymbol{S}$. bradys resistance

Dry rot symptoms and tuber cracking ranged between 0 and 2.4 and $D$. dumetorum var. Nkanfo was apparently symptomless (Table 3). Significant differences $(\mathrm{P}>0.05)$ were also observed between the yams for dry rot disease and tuber cracking.

There were strong correlations $(\mathrm{r}=0.7, \mathrm{r}=0.8)$ between dry rot disease and tuber cracking and number of nematodes in tubers respectively. The pot trial showed that visual damage caused by the yam nematode is useful for evaluation of resistance or susceptibility in Dioscorea.

Although roots supported $S$. bradys reproduction, there was no correlation between susceptibility in roots and tubers. This means that susceptibility in roots cannot be used to select for $S$. bradys resistance in yams. This is probably because the roots responded to stimulatory substances released by the nematode (Reddy, 1987) hence, created a favourable condition for their reproduction and multiplication. Also, it may be that there are nutrients or chemicals in the roots, which nematodes prefer. Developing roots are more tender than tubers so, this might have made it easier for $S$. bradys to penetrate and reproduce. The formation of roots and tubers and functions of these organs could also have played a role, and, probably there was a better $S$. bradys interaction in roots than in tubers.

Figure 2 illustrates the variation in resistance to $S$. bradys in Ghanaian yam varieties. This confirms the resistance of $D$. dumetorum var. Nkanfo and $D$. cayenensis var.Afun to $S$. bradys. The resistance exhibited by these varieties may be due to different physiological processes in them that make it impossible to meet the nutrient requirements of the nematode. This is not likely to be a species difference because $D$. cayenensis var. Abrewa-nwo is susceptible (Table 1). The resistance of $D$. cayenensis is very appreciable because it is easily compatible for hybridisation with D. rotundata (Kwoseh, 2000), the preferred

Table 2: Reaction of 10 selected Ghanaian yam varieties of $D$. rotundata (TDr), D. alata (TDa), D. $c$ ayenensis (TDc) and $D$. dumetorum (TDd) to $S$. bradys resistance at harvest and after eight weeks of storage

\begin{tabular}{|c|c|c|c|c|c|c|c|c|}
\hline \multirow[b]{2}{*}{ Yam variety } & \multicolumn{2}{|c|}{$\begin{array}{c}{ }^{\mathrm{a}} \text { Mean tuber } \\
\text { weight (g) }\end{array}$} & \multicolumn{2}{|c|}{ Tuber weight loss } & \multicolumn{2}{|c|}{$\begin{array}{l}\text { Mean dry } \\
\text { rot index }\end{array}$} & \multicolumn{2}{|c|}{$\begin{array}{c}\text { Mean tuber } \\
\text { Cracking }\end{array}$} \\
\hline & Harvest & 8 wk & \%Loss & ${ }^{*}$ Transformed & Harvest & 8 wk & Harvest & 8 wk \\
\hline TDr Lili & 265.1 & 212.3 & 22.1 & 27.9 & 1.3 & 3.0 & 1.0 & 2.3 \\
\hline TDa Adi-amaaba & 196.3 & 130.8 & 32.0 & 34.4 & 1.0 & 3.0 & 1.0 & 2.3 \\
\hline TDa Yeremma & 447.7 & 326.1 & 24.0 & 28.9 & 0.8 & 2.8 & 0.8 & 1.8 \\
\hline TDa Agyaasi & 97.2 & 54.7 & 49.6 & 44.7 & 0.6 & 2.6 & 0.8 & 1.8 \\
\hline TDr Chenchito & 55.3 & 35.5 & 36.6 & 36.9 & 0.8 & 2.4 & 0.8 & 2.0 \\
\hline TDa Sabiri & 162.1 & 134.6 & 31.0 & 33.2 & 1.0 & 2.2 & 1.0 & 1.6 \\
\hline TDa Matches & 55.6 & 28.3 & 42.8 & 40.5 & 0.7 & 1.3 & 0.7 & 1.3 \\
\hline TDr Sante & 64.9 & 12.1 & 74.5 & 60.1 & 1.0 & 1.0 & 1.0 & 1.0 \\
\hline TDc Afun & 194.4 & 151.0 & 23.1 & 28.6 & 0.2 & 0.2 & 0.2 & 1.0 \\
\hline TDd Nkanfo & 136.9 & 115.7 & 16.0 & 23.5 & 00 & 0.0 & 0.0 & 0.2 \\
\hline $\mathrm{CV}(\%)$ & 80.7 & 78.5 & 43.1 & 25.5 & 69.1 & 47.1 & 64.6 & 40.9 \\
\hline
\end{tabular}

* $\operatorname{Sin}^{-1}$ (\% weight tuber loss/100). ${ }^{a}$ Average of five replicates 


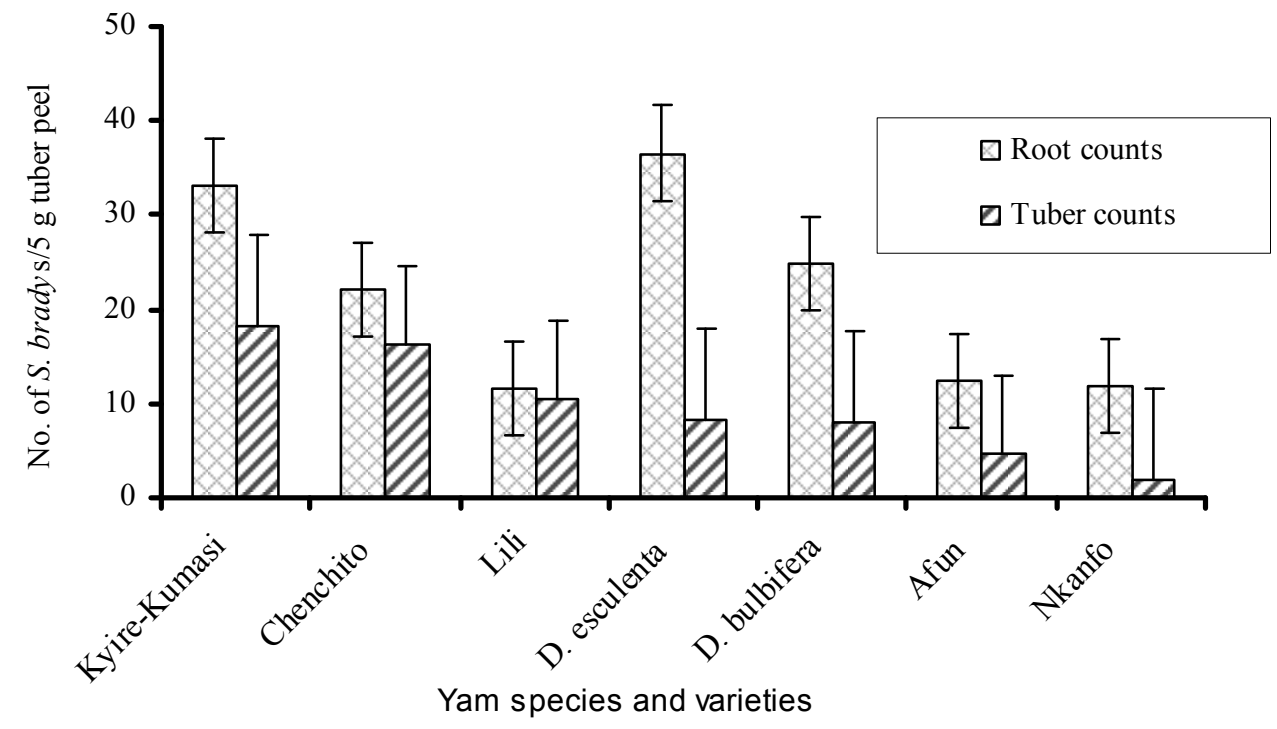

Fig. 2. Square root transformed populations of $S$. bradys in roots and tubers of yams

Table 3: Dry rot symptom scores in selected Ghanaian yam varieties of five Dioscorea species to $S$. bradys in pots nine weeks after inoculation

\begin{tabular}{lcc}
\hline \multicolumn{1}{c}{ Yam varieties \& species } & Mean* tuber cracking & Mean dry rot index \\
\hline TDr Chenchito & 2.4 & 2.4 \\
TDr Kyire-Kumasi & 2.0 & 2.0 \\
TDr Lili & 1.8 & 1.8 \\
TDc Afun & 0.8 & 1.0 \\
D. bulbifera & 0.5 & 0.7 \\
TDd Nkanfo & 0.5 & 0.0 \\
D. esculenta & 0.5 & 0.0 \\
CV $(\%)$ & 54.0 & 61.8 \\
\hline
\end{tabular}

*Average of five replicates. Yam species: TDr: D. rotundata, TDc: D. cayenensis, TDd: D. dumetorum

food or edible species. According to Asiedu et al. (1998), D. rotundata, D. praehensilis, D. cayenensis, D. dumentorum and D. burklilliana have been used in inter specific crosses and there are efforts in advanced laboratories aimed at somatic embryogenesis, somatic hybridisation and generic transformation.
In general, the benefit-to-cost ratio of breeding nematode resistant varieties is economically beneficial (Starr et al., 2002), particularly, to the resource-poor farmers. The identification of the resistant genotypes or sources of resistance would constitute the beginning of more focused effort in breeding for host plant resistance. Therefore, the 
information developed in this study should greatly help in yam breeding programmes for the continued search of nematode resistance in Dioscorea.

\section{CONCLUSIONS}

The conclusions derived from the study are as follows:

- In general, S. bradys population density and dry rot disease of yam tuber as well as tuber cracking increased with storage. This shows that the yam nematode is a serious storage pest.

- $\quad$ An efficient, positive pot and field screening methodologies with improved precision have been developed to make meaningful selections from yam germplasm.

- Results demonstrated a linear relationship between nematode damage and population densities in yam tubers, implying visual disease symptoms are useful parameters for rating host resistance in yams. Dry rot symptoms of yams could therefore be used to discard susceptible yam varieties at harvest and after a period of storage.

- $\quad$ There was no correlation between $S$. bradys susceptibility in roots and tubers, therefore, within the limits of this study a root protocol cannot be used for assessing resistance in yams as it could give misleading classification.

- $\quad$ Based on S. bradys populations, all the yam varieties of $D$. rotundata and $D$. alata in the screen were susceptible however, there was a high variation in susceptibility between the yam varieties.

- Tuber weight reduction among the yams was substantial after a period of storage. There was also a positive correlation between tuber weight loss and dry rot disease indicating that dry rot disease may have contributed to the tuber weight loss.

- D. dumetorum var. Nkanfo and $D$. cayenensis var. Afun were resistant to $S$. bradys. These yams are considered resistant because they did not support multiplication of $S$. bradys or had relatively smaller dry rot damage and supported very small nematode populations.

- Mass screening of yam germplasm using the yam minisett both in field and pot trials is practical and convenient considering the cost of tissue culture material. Mounds and ridges should be infested with infected yam peelings to avoid escapes.

\section{REFERENCES}

Adesiyan, S. O. (1977). Penetration and multiplication of Scutellonema bradys in yams (Dioscorea spp.). Nematologia mediterranea 5: $313-317$.

Adesiyan, S. O., Caveness, F. E., Adeniji, M. O. and Fawole, B. (1990). Nematode pests of tropical crops. Heinemann Educational Books (Nigeria) Limited.114 pp.

Akoroda, M. O. and Hahn, S. K. (1995). Yams in Nigeria: status and trends. African Journal of Root and Tuber Crops 1: 37-41.

Asiedu, R., Ng, N. Y. C., Bai, K. V., Ekanayake, I. J. and Wanyera, N. M. W. (1998). Genetic improvement. In: Food yams: Advances in research, (eds.) G. C. Orkwor, R. Asiedu and I. J. Ekanayake. pp. 63-104.

Bridge, J. (1982). Nematodes of yams. In: Yams. Igname, (eds.) J. Miege and S. N. Lyonga, Clarendon Press, Oxford. pp. 253-264.

Bridge, J., Coyne, D. L. and Kwoseh, C. K. (2005). Nematode parasites of tropical root and tuber crops. $2^{\text {nd }}$ Edition. In: Plant Parasitic nematodes in subtropical and tropical agriculture, (eds.) M. Luc, R. A. Sikora and J. Bridge, CAB International, UK. pp. 221258.

Cook R. and Evans, K. (1987). Resistance and tolerance. In: Principles and practice of nematode control in crops, (eds.) R. H. 
Brown and B. R. Kerry. Academic Press. pp.179-231.

Coursey, D. G. (1967). Yams. Longmans, Green and Co. Ltd., London.. 230 pp.

Degras, L. M. (1993). The Yam: A tropical Root Crop. The Technical Centre for Agricultural and Rural Cooperation (CTA). The MacMillan Press, London. 408 pp.

Emehute, J. K. U., Ikotun, T., Nwauzor, E. C. and Nwokocha, H. N. (1998). Crop p r o tection. In: Food yams: Advances in Research, (eds.) G. C. Orkwor, R. Asiedu and I. J. Ekanayake. pp. 141-186.

Jatala, P. and Bridge, J., (1990). Nematode parasites of root and tuber crops. In: Plant Parasitic nematodes in subtropical and tropical agriculture, (eds.) M. Luc, R. A. Sikora and J. Bridge, CAB International, UK. pp.137 - 180.

Kwoseh, C. K. (2000). Identification of resistance to major nematode pest of yams (Dioscorea spp.) in West Africa. PhD thesis. Dept of Agriculture, University of Reading, UK.196 pp.
Kwoseh, C., Plowright, R. A. and Bridge, J. (2002). The yam nematode: Scutellonema bradys. In: Plant resistance to parasitic nematodes, (eds.) J. L. Starr, R. Cook and J. Bridge, CAB International, UK. pp.258.

Otoo, J. A., Osiru, D. S. O, Ng, S. Y. C and Hahn, S. K. (1987). Improved technology for seed yam production. IITA, Ibadan, Nigeria. $56 \mathrm{pp}$.

Plowright, R. A and Kwoseh, C. K. (1998). Farmers perceptions of nematode disease in yams in Ghana and the prevalence of endoparasitic nematodes in stored tubers. Nematologica 44: 558-559 (Abstract).

Reddy, P. P. (1987). A treatise on phytonematology. Agricole Pub. Academy, India.381 pp

SAS (1996). SAS Institute Incorporated, Cary, NC, USA.

Starr, J. L., Bridge, J. and Cook, R. (2002). Resistance to plant-parasitic nematodes: History, current use and future potential In: Plant resistance to parasitic nematodes, (eds.) J. L. Starr, R. Cook and J. Bridge, CAB Interna-

42 Journal of Science and Technology, Vol. 27, No. 3, December 2007 